\title{
Article
}

\section{On the Nature of "RuCl(dmso)\{HB(mt)\}" (mt = methimazolyl)}

Robyn J. Abernethy, Anthony F. Hill, Never Tshabang, Anthony C. Willis, and Rowan D. Young Organometallics, 2009, 28 (2), 488-492 • DOI: 10.1021/om8007426 • Publication Date (Web): 19 December 2008

Downloaded from http://pubs.acs.org on January 26, 2009
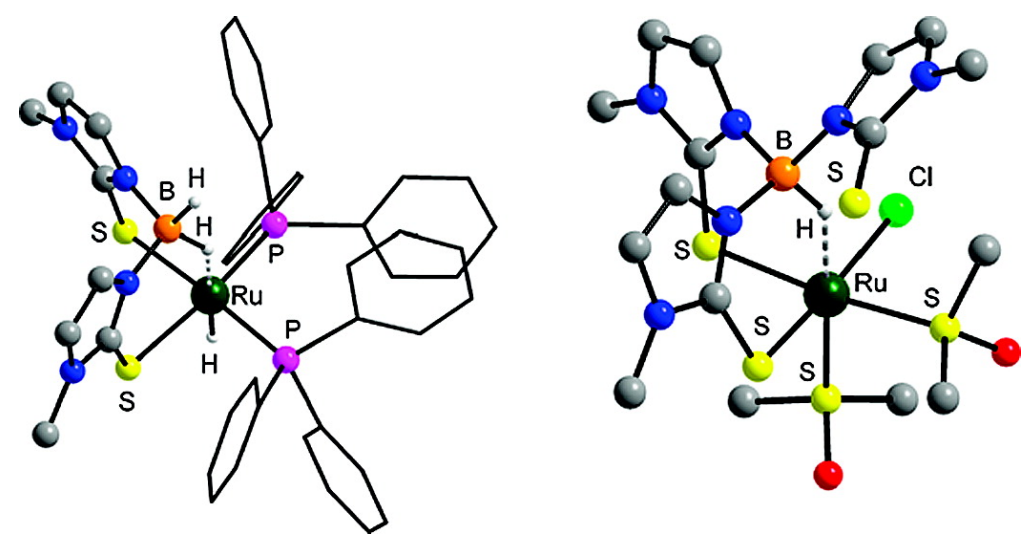

\section{More About This Article}

Additional resources and features associated with this article are available within the HTML version:

- $\quad$ Supporting Information

- Access to high resolution figures

- $\quad$ Links to articles and content related to this article

- Copyright permission to reproduce figures and/or text from this article

\section{View the Full Text HTML}




\title{
On the Nature of " $\mathrm{RuCl}(\mathrm{dmso})_{2}\left\{\mathrm{HB}(\mathrm{mt})_{3}\right\}$ " (mt $=$ methimazolyl $)$
}

\author{
Robyn J. Abernethy, Anthony F. Hill,* Never Tshabang, Anthony C. Willis, and \\ Rowan D. Young \\ Research School of Chemistry, Institute of Advanced Studies, Australian National University, \\ Canberra, ACT, Australia
}

Received July 31, 2008

\begin{abstract}
The high-yield product of the reaction of $\left[\mathrm{RuCl}_{2}\left(\mathrm{dmso}_{4}\right]\left(\mathrm{dmso}=\right.\right.$ dimethylsulfoxide) with $\mathrm{Na}\left[\mathrm{HB}(\mathrm{mt})_{3}\right]$ $(\mathrm{mt}=$ methimazolyl $)$ is not, as reported, the complex $\left[\mathrm{RuCl}(\mathrm{dmso})_{2}\left\{\kappa^{3}-S, S^{\prime}, S^{\prime \prime}-\mathrm{HB}(\mathrm{mt})_{3}\right\}\right]$ but rather the isomeric $\left[\mathrm{RuCl}(\mathrm{dmso})_{2}\left\{\kappa^{3}-H, S, S^{\prime}-\mathrm{HB}(\mathrm{mt})_{3}\right\}\right]$, which features a three-center, two-electron $\mathrm{B}-\mathrm{H}-\mathrm{Ru}$ interaction, as also found for the complex $\left[\mathrm{RuH}\left(\mathrm{PPh}_{3}\right)_{2}\left\{\kappa^{3}-H, S, S^{\prime}-\mathrm{H}_{2} \mathrm{~B}(\mathrm{mt})_{2}\right\}\right]$, which results from $\left[\mathrm{RuHCl}\left(\mathrm{PPh}_{3}\right)_{3}\right]$ and $\mathrm{Na}\left[\mathrm{H}_{2} \mathrm{~B}(\mathrm{mt})_{2}\right]$.
\end{abstract}

\section{Introduction}

Within the growing field of poly(methimazolyl)borate chemistry (Chart 1), three-center, two-electron $\mathrm{B}-\mathrm{H}-$ metal interactions appear to be a recurrent feature of the binding of these and related ligands to transition metals. ${ }^{1}$ It has been suggested that they are important intermediates in the formation of metallaboratranes via $\mathrm{B}-\mathrm{H}$ activation. ${ }^{2,3}$ Although potentially more far-reaching routes to compounds with $\mathrm{B} \rightarrow \mathrm{M}$ dative bonding have now been demonstrated by Bourissou, ${ }^{4}$ the facile $\mathrm{B}-\mathrm{H}$ activation of poly(methimazolyl)borates by late transition metals remains a remarkably general route. ${ }^{2,3}$ Within scorpionate chemistry, $\mathrm{B}-\mathrm{H}-\mathrm{M}$ interactions are of course not unheard of, the first examples having being encountered for simple dihydrodbis(dimethylpyrazolyl)borates of molybdenum some 35

* To whom correspondence should be addressed. E-mail: a.hill@ anu.edu.au.

(1) (a) Kimblin, C.; Churchill, D. G.; Bridgewater, B. M.; Girard, J. N. Quarless, D. A.; Parkin, G. Polyhedron 2001, 20, 1891. (b) Kimblin, C.; Bridgewater, B. M.; Churchill, D. G.; Hascall, T.; Parkin, G. Inorg. Chem. 2000, 39, 4240. (c) Dodds, C. A.; Garner, M.; Reglinski, J.; Spicer, M. D. Inorg. Chem. 2006, 45, 2733. (d) Graham, L. A.; Fout, A. R.; Kuehne, K. R.; White, J. L.; Mookherji, B.; Marks, F. M.; Yap, G. P. A.; Zakharov, L. N.; Rheingold, A. L.; Rabinovich, D. Dalton Trans. 2005, 171. (e) Alvarez, H. M.; Tanski, J. M.; Rabinovich, D. Polyhedron 2004, 23, 395. (f) Alvarez, H. M.; Krawiec, M.; Donovan-Merkert, B. T.; Fouzi, M.; Rabinovich, D. Inorg. Chem. 2001, 40, 5736. (g) Kuan, S. L.; Leong, W. K.; Goh, L. Y.; Webster, R. D. J. Organomet. Chem. 2006, 691, 907. (h) Kuan, S. L.; Leong, W. K.; Goh, L. Y.; Webster, R. D. Organometallics 2005 , 24, 4639. (i) Foreman, M. R.; St., J.; Hill, A. F.; Tshabang, N.; White, A. J. P.; Williams, D. J. Organometallics 2003, 22, 5593. (j) Hill, A. F. Smith, M. K.; Wagler, J. Organometallics 2008, 27, 2137. (k) Hill, A. F.; Smith, M. K. Chem. Commun. 2005, 1920. (1) Abernethy, R. J.; Hill, A. F.; Neumann, H.; Willis, A. C. Inorg. Chim. Acta 2005, 358, 1605. (m) Hill, A. F.; Smith, M. K. Organometallics 2007, 26, 3900. (n) Crossley, I. R.; Hill, A. F.; Willis, A. C. Organometallics 2007, 26, 3891. (o) Crossley, I. R.; Hill, A. F.; Humphrey, E. R.; Smith, M. K. Organometallics 2006, 25, 2242. (p) Foreman, M. R.; St, J.; Hill, A. F.; Smith, M. K.; Tshabang, N. Organometallics 2005, 24, 5224. (q) Crossley, I. R.; Hill, A. F.; Willis, A. C. Organometallics 2005, 24, 4889. (r) Abernethy, R. J.; Foreman, M. R. St.-J.; Hill, A. F.; Tshabang, N.; Willis, A. C.; Young, R. D. Organometallics 2008, in press. (s) Gennari, M.; Lanfranchi, M.; Marchio, L.; Pellinghelli, M. A.; Tegoni, M.; Cammi, R. Inorg. Chem. 2006, 45, 3456. (t) Santini, C.; Pettinari, C.; Gioia Lobbia, G.; Spagna, R.; Pellei, M.; Vallorani, F. Inorg. Chim. Acta 1999, 285, 81. (u) Maria, L.; Moura, C.; Paulo, A.; Santos, I. C.; Santos, I. J. Organomet. Chem. 2006, 691, 4773. (v) Garcia, R.; Xing, Y.-H.; Paulo, A.; Domingos, A.; Santos, I. J. Chem. Soc., Dalton Trans. 2002, 4236. (w) Garcia, R.; Domingos, A.; Paulo, A.; Santos, I.; Alberto, R. Inorg. Chem. 2002, 41, 2422. (x) Maria, L.; Domingos, A.; Santos, I. Inorg. Chem. 2001, 40, 6863. (y) Garcia, R.; Paulo, A.; Domingos, A.; Santos, I.; Ortner, K.; Alberto, R. J. Am. Chem. Soc. 2000, 122, 11240. ago. ${ }^{5}$ Nevertheless, evidence continues to accumulate to suggest that such interactions are especially favorable for bis(methimazolyl)borate complexes, ${ }^{1}$ presumably a corollary of the increased chelate size that attends replacement of pyrazolyl groups (BNNM) with methimazolyl (BNCSM) bridges. Indeed, we have previously shown that even the $\mathrm{HB}(\mathrm{mt})_{3}$ ligand may adopt this coordination mode $\left(\kappa^{3}-H, S, S^{\prime}\right)$ in preference to the more commonly observed $\kappa^{3}-S, S^{\prime}, S^{\prime \prime}$ mode, e.g., the complex [RuH$\left.(\mathrm{CO})\left(\mathrm{PPh}_{3}\right)\left\{\mathrm{HB}(\mathrm{mt})_{3}\right\}\right](\mathbf{1}){ }^{6}$ The spontaneous reaction of $\mathbf{1}$ with

(2) (a) Hill, A. F.; Owen, G. R.; White, A. J. P.; Williams, D. J. Angew. Chem., Int. Ed. 1999, 38, 2759. (b) Foreman, M. R. St.-J.; Hill, A. F.; White, A. J. P.; Williams, D. J. Organometallics 2004, 23, 913. (c) Crossley, I. R.; Foreman, M. R. St.-J.; Hill, A. F.; White, A. J. P.; Williams, D. J. Chem. Commun. 2005, 221. (d) Crossley, I. R.; Hill, A. F.; Humphrey, E. R.; Willis, A. C. Organometallics 2005, 24, 4083. (e) Crossley, I. R.; Hill, A. F.; Willis, A. C. Organometallics 2006, 25, 289. (f) Crossley, I. R.; Hill, A. F.; Willis, A. C. Organometallics 2005, 24, 1062. (g) Crossley, I. R.; Hill, A. F.; Willis, A. C. Organometallics 2006, 25, 289. (h) Crossley, I. R.; Hill, A. F. Organometallics 2004, 23, 5656. (i) Crossley, I. R.; Hill, A. F.; Willis, A. C. Organometallics 2007, 26, 3891. (j) Crossley, I. R.; Hill, A. F. Dalton Trans. 2008, 231. (k) Crossley, I. R.; Hill, A. F.; Willis, A. C. Organometallics 2008, 27, 312. (1) Crossley, I. R.; Foreman, M. R.; St, J.; Hill, A. F.; Owen, G. R.; White, A. J. P.; Williams, D. J.; Willis, A. C. Organometallics 2008, 27, 381.

(3) (a) Mihalcik, D. J.; White, J. L.; Tanski, J. M.; Zakharov, L. N.; Yap, G. P. A.; Incarvito, C. D.; Rheingold, A. L.; Rabinovich, D. Dalton Trans. 2004, 1626. (b) Blagg, R. J.; Charmant, J. P. H.; Connelly, N. G.; Haddow, M. F.; Orpen, A. G. Chem. Commun. 2006, 2350. (c) Senda, S.; Ohki, Y.; Yasuhiro, H.; Tomoko, T.; Toda, D.; Chen, J.-L.; Matsumoto, T.; Kawaguchi, H.; Tatsumi, K. Inorg. Chem. 2006, 45, 9914. (d) Landry, V.; Melnick, J. G.; Buccella, D.; Pang, K.; Ulichny, J. C.; Parkin, G. Inorg. Chem. 2006, 45, 2588. (e) Figueroa, J. S.; Melnick, J. G.; Parkin, G. Inorg. Chem. 2006, 45, 7056. (f) Pang, K.; Quan n, S. M.; Parkin, G. Chem. Commun. 2006, 5015. (g) Pang, K.; Tanski, J. M.; Parkin, G. Chem. Commun. 2008, 1008.

(4) (a) Bontemps, S.; Gornitzka, H.; Bouhadir, G.; Miqueu, K.; Bourissou, D. Angew Chem., Int. Ed. 2006, 45, 1611. (b) Bontemps, S.; Bouhadir, G.; Miqueu, K.; Bourissou, D. J. Am. Chem. Soc. 2006, 128, 12056. (c) Bontemps, S.; Sircoglou, M.; Bouhadir, G.; Puschmann, H.; Howard, J. A. K.; Dyer, P. W.; Miqueu, K.; Bourissou, D. Chem.-Eur. J. 2008, 14, 731. (d) Sircoglou, M.; Bontemps, S.; Mercy, M.; Saffon, N.; Takahashi, M.; Bouhadir, G.; Maron, L.; Bourissou, D. Angew. Chem., Int. Ed. 2007, 46, 8583. (e) Bebbington, M. W. P.; Bouhadir, G.; Bourissou, D. Eur. J. Org. Chem. 2007, 4483. (f) Bontemps, S.; Bouhadir, G.; Gu, W.; Mercy, M.; Chen, C.-H.; Foxman, B. M.; Maron, L.; Ozerov, O. V.; Bourissou, D. Angew. Chem., Int. Ed. 2008, 47, 1481.

(5) (a) Trofimenko, S. Scorpionates: The Coordination of Polypyrazolylborate Ligands; Imperial College Press: London, 1999. (b) Rheingold, A. L.; Liable-Sands, L. M.; Incarvito, C. L.; Trofimenko, S. Dalton Trans. 2002, 2297. (c) Chowdhury, S. K.; Samanta, U.; Puranik, V. G.; Sarkar, A. Organometallics 1997, 16, 2618. (d) Kosky, C. A.; Ganis, P.; Avitabile, G. Acta Crystallogr., Sect. B: Struct. Crystallogr. Cryst. Chem. 1971, 27, 1859. 
Chart 1. (a) $\kappa^{2}-S, S^{\prime}$-Dihydrobis(methimazolyl)borato, (b) $\kappa^{3}$ $H, S, S^{\prime}$-Dihydrobis(methimazolyl)borato, (c) $\kappa^{3}-S, S^{\prime}, S^{\prime \prime}$ - Hydrotris(methimazolyl)borato, and (d) $\kappa^{4}-B, S, S^{\prime}, S^{\prime \prime}$-Tris(methimazolyl)borane ("metallaboratrane") Complexes<smiles>C=CSC1N(C)C=CN1C</smiles>

(a)<smiles>[H][R3]1([H])CSSCN1</smiles>

(c)<smiles></smiles>

(b)

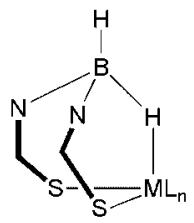

(d)

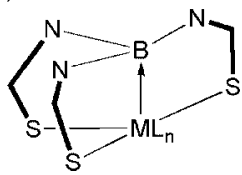

ethynylbenzene under ambient conditions to provide styrene and the archetypal metallaboratrane ${ }^{7-9}\left[\mathrm{Ru}(\mathrm{CO})\left(\mathrm{PPh}_{3}\right)\left\{\mathrm{B}(\mathrm{mt})_{3}\right\}\right]-$ $(R u \rightarrow B)^{8}$ would, however, appear to indicate that the $\mathrm{B}-\mathrm{H}-\mathrm{Ru}$ interaction is, in this case, hemilabile.

Against this background, we were intrigued by the report of a complex, $\left[\mathrm{RuCl}(\mathrm{dmso})_{2}\left\{\mathrm{HB}(\mathrm{mt})_{3}\right\}\right](2),{ }^{10}$ obtained as redorange crystals $(19 \%)$ from the reaction of $\left[\mathrm{RuCl}_{2}(\mathrm{dmso})_{4}\right]^{11}$ with $\mathrm{Na}\left[\mathrm{HB}(\mathrm{mt})_{3}\right]^{2 \mathrm{a}}$ On the basis of an imprecise crystallographic study $(R \approx 0.20)$ supported by infrared and ${ }^{1} \mathrm{H}$ NMR data, 2 was formulated as involving $\kappa^{3}-S, S^{\prime}, S^{\prime \prime}$ coordination of a $\mathrm{HB}(\mathrm{mt})_{3}$ ligand. Our problem with this formulation was the inconsistency of the limited spectroscopic data with the solid state structure. Specifically, (i) an IR absorption was reported at $2198 \mathrm{~cm}^{-1}$ that was attributed to the terminal $\mathrm{B}-\mathrm{H}$ stretch, while this region corresponds more closely to that typical of a $\mathrm{B}-\mathrm{H}-\mathrm{Ru}$ interaction. ${ }^{1,6}$ (ii) The solid state structure has no element of symmetry due to the intrinsic chirality of the $\mathrm{HB}(\mathrm{mt})_{3} \mathrm{Ru}$ cage, inversion of which in related ruthenium complexes $^{12}$ has been shown to be a high-energy process that does not operate under mild conditions, if at all. ${ }^{13}$ Thus the NMR data, which were claimed to comprise two singlet methyl resonances $\left(\delta_{\mathrm{H}}\left(d_{6}\right.\right.$-dmso $\left.)=2.55\left(\mathrm{SCH}_{3}\right), 3.30\left(\mathrm{NCH}_{3}\right)\right)$ for the bulk sample, are not consistent with the molecular structure of 2, which has seven chemically distinct methyl environments.

(6) Foreman, M. R.; St, J.; Hill, A. F.; Owen, G. R.; White, A. J. P.; Williams, D. J. Organometallics 2003, 22, 4446.

(7) There is some debate in the literature 8,9 as to how best to describe the bonding of metallaboratranes. The debate centers on whether the formation of a metal-boron dative bond represents a two-electron oxidation of the metal center and increase in valency and/or oxidation state by two units. Experimental evidence germane to this debate continues to accumulate ${ }^{4}$ and in the interim we recommend a nomenclature that rises above semantics by following line formulas for metallaboratranes with the $(M \rightarrow B)^{n}$ notation where $n$ represents the total number of d-electrons, including those involved to some variable extent in the formation of the $\mathrm{M} \rightarrow \mathrm{B}$ bond. ${ }^{8}$

(8) Hill, A. F. Organometallics 2006, 25, 4741.

(9) Parkin, G. Organometallics 2006, 25, 4744.

(10) Bailey, P. J.; Lorono-Gonzales, D. J.; McCormack, C.; Parson, S.; Price, M. Inorg. Chim. Acta 2003, 354, 61.

(11) Evans, I. P.; Spencer, A.; Wilkinson, G. J. Chem. Soc., Dalton Trans. 1973, 204.

(12) Bailey, P. J.; Dawson, A.; McCormack, C.; Moggach, S. A.; Oswald, D. H.; Parsons, S.; Rankin, D. W. H.; Turner, A. Inorg. Chem. 2005, 44, 8884 .

(13) (a) In other systems it should however be noted that cage inversion may be facile, though a dissociative $\mathrm{S}-\mathrm{W}$ mechanism has been invoked: (b) Foreman, M. R. St.-J.; Hill, A. F.; White, A. J. P.; Williams, D. J. Organometallics 2003, 22, 3831.
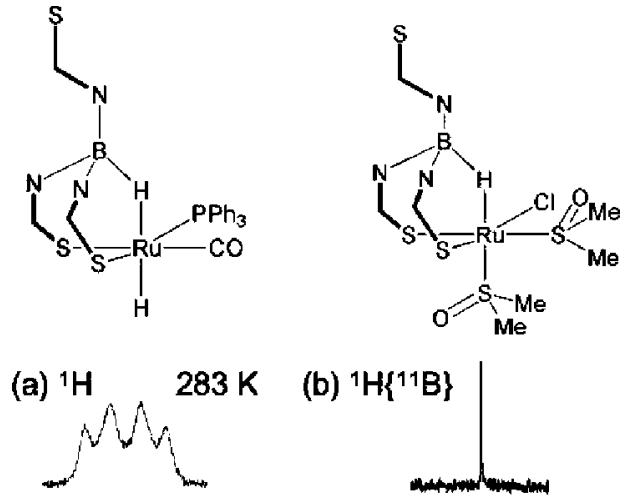

(b) ${ }^{1} \mathrm{H}\left\{{ }^{11} \mathrm{~B}\right\}$

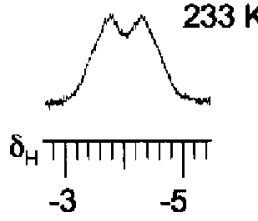

(c) ${ }^{1} \mathrm{H}$

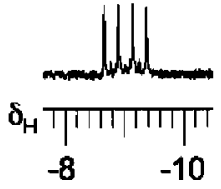

Figure 1. ${ }^{1} \mathrm{H}$ NMR spectra of $\mathrm{B}-\mathrm{H}-\mathrm{Ru}$ complexes: (a) $\mathbf{1}\left({ }^{1} \mathrm{H}\right) ;{ }^{2 \mathrm{~b}}$ (b) $3\left({ }^{1} \mathrm{H}\left\{{ }^{11} \mathrm{~B}\right\}\right)$; and (c) $3\left({ }^{1} \mathrm{H}\right)$.

We report herein the full characterization of the major product (up to $92 \%$ of the crude material) of the reaction of $\left[\mathrm{RuCl}_{2}(\mathrm{dmso})_{4}\right]$ with $\mathrm{Na}\left[\mathrm{HB}(\mathrm{mt})_{3}\right]$, which is in fact the bright orange complex $\left[\mathrm{RuCl}(\mathrm{dmso}-S)_{2}\left\{\kappa^{3}-H, S^{\prime} S^{\prime \prime}-\mathrm{HB}(\mathrm{mt})_{3}\right\}\right]$ (3). In addition, a further example of a complex adopting the $\kappa^{3}-H, S, S^{\prime}$ coordination mode, $\left[\mathrm{RuH}\left(\mathrm{PPh}_{3}\right)_{2}\left\{\mathrm{H}_{2} \mathrm{~B}(\mathrm{mt})_{2}\right\}\right]$, is reported as evidence in support of the prevalence of this coordination mode.

\section{Results and Discussion}

In contrast to the reported reaction of $\left[\mathrm{RuCl}_{2}(\mathrm{dmso})_{4}\right]$ with $\mathrm{Na}\left[\mathrm{HB}(\mathrm{mt})_{3}\right]$ in dichloromethane to provide a brown ${ }^{10}$ solution we find that combining these reagents anaerobically in tetrahydrofuran results in the formation of a dark orange solution over $3 \mathrm{~h}$. Removal of the solvent in vacuo and measurement of the ${ }^{1} \mathrm{H}$ NMR spectrum of the bulk sample indicates that it comprises approximately $90-95 \%$ of a single compound (vide infra). This composition does not change appreciably if the mixing time is extended to $24 \mathrm{~h}$. Considerable losses however attend purification by extraction and fractional crystallization to remove the salt side product such that yields of the pure isolated, salt-free product range from 40 to $60 \%$. Spectroscopic data for the product are superficially as expected (and distinct from those reported ${ }^{10}$ ) for the solid state structure in that seven methyl resonances are observed in both the ${ }^{1} \mathrm{H}$ and ${ }^{13} \mathrm{C}$ NMR spectra, indicative of a lack of any symmetry element in the complex. However, both the solution (THF: $2226 \mathrm{~cm}^{-1}$ ) and solid state (Nujol: $2206 \mathrm{~cm}^{-1}$ ) infrared spectra include absorptions in the region characteristic of $\mathrm{B}-\mathrm{H}-\mathrm{Ru}$ rather than terminal $\mathrm{B}-\mathrm{H}$ stretches. ${ }^{1}$ This prompted us to measure the ${ }^{1} \mathrm{H}$ NMR spectra to high frequency of $\mathrm{SiMe}_{4}$, where a remarkably well-resolved $1: 1: 1: 1$ quartet may be found $\left(\delta_{\mathrm{H}}=-9.02,{ }^{1} J_{\mathrm{BH}}=71.6 \mathrm{~Hz}\right.$, Figure 1) in the region typical of $\mathrm{B}-\mathrm{H}-\mathrm{M}$ interactions. We have often had recourse to this spectroscopic signature, but have never encountered a situation where the boron quadrupole is so effectively decoupled, especially when the boron experiences such an asymmetric electric field gradient. Such sharp lines are typically characteristic of cubic electric fields about boron, e.g., $\mathrm{Na}\left[\mathrm{BH}_{4}\right]$. Indeed the resolution is such that the heptet resonance for the ${ }^{10} \mathrm{~B}$ isotopomer is also discernible, displaying the expected ${ }^{1} \mathrm{~J}_{\mathrm{BH}}$ coupling $\left(24.0 \mathrm{~Hz}, v\left({ }^{10} \mathrm{~B}\right) / v\left({ }^{11} \mathrm{~B}\right)=3.0\right)$. This 


\section{Scheme 1. Synthesis of $\mathrm{HB}(\mathrm{mt})_{3}$ Complexes of Ruthenium}

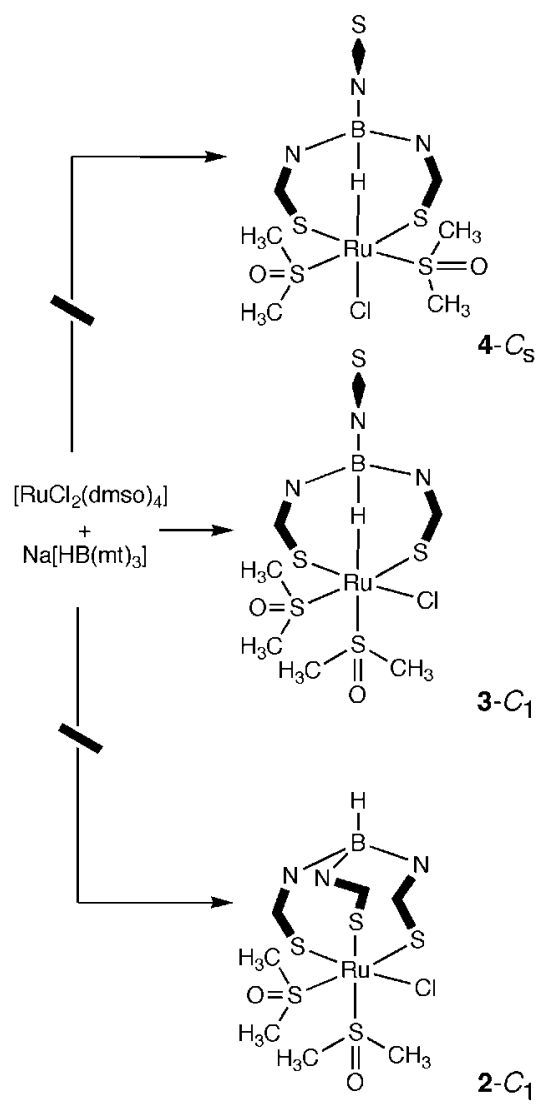

resonance collapses to a singlet in the boron-decoupled spectrum. The ${ }^{11} \mathrm{~B}$ NMR spectrum comprises a doublet $\left(\delta_{\mathrm{B}}=0.99\right.$ ppm, ${ }^{1} J_{\mathrm{BH}}=73.2 \mathrm{~Hz}$ ), which collapses to a singlet in the ${ }^{11} \mathrm{~B}\left\{{ }^{1} \mathrm{H}\right\}$ spectrum.

Thus, the alternative, low-symmetry isomer for $\mathbf{2}$ must account for these data, indicated as $\mathbf{3}$ in Scheme 1. The more symmetric isomer 4, which also involves $\kappa^{3}-H, S, S^{\prime}$ coordination, may be discarded in that it has overall $C_{s}$ symmetry and would therefore give rise to four different methyl resonances. The molecular geometry of $\mathbf{3}$ was confirmed in the solid state by a crystallographic study, the results of which are summarized in Figure 2.

The geometry at ruthenium is essentially octahedral when the constraints of chelation are taken into account. Thus all interligand angles are close to $90^{\circ}$, the smallest of these $\left(\mathrm{Cl1}-\mathrm{Ru} 1-\mathrm{S} 287.91(5)^{\circ}\right)$ being traced to an apparent weak interaction between the $\mathrm{B}-\mathrm{H}-\mathrm{Ru}$ group and two of the protons on $\mathrm{C} 22(\mathrm{~B} 1 \mathrm{H} 1 \cdots \mathrm{HC} 22=2.82,2.62 \AA)$, though hydrogen positions adjacent to heavy atoms should not be overscrutinized. The protons of dmso are weakly acidic in nature, and this would be expected to increase upon coordination to Lewis acidic ruthenium(II), while the $\mathrm{B}-\mathrm{H}$ group is characteristically hydridic in nature. The ${ }^{1} \mathrm{H}$ NMR spectrum of $\mathbf{3}$ has one $\mathrm{S}-\mathrm{CH}_{3}$ resonance shifted somewhat upfield of the remainder, and it is this resonance that displays an NOE correlation with the borohydride resonance. It might therefore be inferred that this is not a solid state artifact, but quite possibly persists in solution. There is also an NOE correlation observed between the hydride resonance and one aromatic methimazolyl resonance, which presumably corresponds to the $5-H$ proton on the unique pendant methimazolyl group $(\mathrm{H} \cdots \mathrm{H}=3.02 \AA)$. The two dimethylsulfoxide ligands have significantly different (30 esd) $\mathrm{Ru}-\mathrm{S}$ bond lengths, with that trans to the $\mathrm{B}-\mathrm{H}-\mathrm{Ru}$ interaction being noticeably shorter. Thus the three-center, two-electron interaction would appear to exert an inverse trans influence, presumably due to the weakness of the $\mathrm{H} \cdots \mathrm{Ru}$ interaction.

Having established the identity of $\mathbf{3}$, the questions as to the nature of " 2 " remain. As noted above, the bulk spectroscopic data reported are inconsistent with the crystallographic data, which perhaps relate to a "rogue" crystal. We have been unable to identify conditions that provide any isomer other than $\mathbf{3}$ from the reaction of $\left[\mathrm{RuCl}_{2}(\mathrm{dmso})_{4}\right]$ with $\mathrm{Na}\left[\mathrm{HB}(\mathrm{mt})_{3}\right]$. Indeed, repeating the reaction of $\left[\mathrm{RuCl}_{2}(\mathrm{DMSO})_{4}\right]$ with $\mathrm{Na}\left[\mathrm{HB}(\mathrm{mt})_{3}\right]$ in $\mathrm{CD}_{2} \mathrm{Cl}_{2}$ under conditions identical to those reported ${ }^{10}$ gives primarily (ca. 70\%) 3. Removal of the $\mathrm{CD}_{2} \mathrm{Cl}_{2}$ and dissolving the entire residue in $d_{6}$-dmso provided a spectrum devoid of the resonances reported for $\mathbf{2}$, although it should be noted that the single $\mathrm{SCH}_{3}$ resonance that was reported $\left(\delta_{\mathrm{H}} 2.55\right)$ would not have been discernible beneath the broad signal due to residual dmso. These spectra are provided as Supporting Information.

We have previously noted that ligand fragmentation attends the reaction of $\mathrm{Na}\left[\mathrm{HB}(\mathrm{mt})_{3}\right]$ with $\left[\mathrm{RuCl}_{2}\left(\mathrm{PPh}_{3}\right)_{3}\right]$ such that $\left[\mathrm{Ru}\left(\kappa^{2}-N, S-\mathrm{mt}\right)_{2}\left(\mathrm{PPh}_{3}\right)_{2}\right]$ is the only isolated complex, to date. ${ }^{14}$ Furthering our studies of $\mathrm{B}-\mathrm{H}-$ metal interactions with poly(methimazolyl)borates, we have now investigated the reaction of $\left[\mathrm{RuHCl}\left(\mathrm{PPh}_{3}\right)_{3}\right] \cdot \mathrm{C}_{6} \mathrm{H}_{5} \mathrm{Me}^{15}$ with $\mathrm{Na}\left[\mathrm{H}_{2} \mathrm{~B}(\mathrm{mt})_{2}\right]^{1 \mathrm{i}}$ and find that, in contrast, a clean reaction ensues to provide a hydrido complex formulated as $\left[\mathrm{RuH}\left(\mathrm{PPh}_{3}\right)_{2}\left\{\mathrm{H}_{2} \mathrm{~B}(\mathrm{mt})_{2}\right\}\right]$ (5) on the basis of spectroscopic and elemental microanalytical data. The mass spectrum is devoid of an isotopic cluster attributable to a tris(phosphine) complex $\left[\mathrm{RuH}\left(\mathrm{PPh}_{3}\right)_{3}\left\{\mathrm{H}_{2} \mathrm{~B}(\mathrm{mt})_{2}\right\}\right]$, though this is not necessarily definitive. However, the ${ }^{31} \mathrm{P}\left\{{ }^{1} \mathrm{H}\right\}$ NMR spectrum shows a single phosphorus environment, which would not be possible for a static tris(phosphine) complex. Thus we were drawn to the conclusion that the complex has only two, chemically equivalent, phosphine ligands and either is coordinatively unsaturated or involves a further example of a $\mathrm{B}-$ $\mathrm{H}-\mathrm{Ru}$ association, viz., [ $\left.\mathrm{RuH}\left(\mathrm{PPh}_{3}\right)_{2}\left\{\kappa^{3}-H, S, S^{\prime}-\mathrm{H}_{2} \mathrm{~B}(\mathrm{mt})_{2}\right\}\right]$. This conclusion was substantiated by the usual $\mathrm{B}-\mathrm{H}-\mathrm{M}$ spectroscopic signatures $\left(\delta_{\mathrm{H}}=-5.7 \mathrm{ppm} ; v_{\mathrm{BHRu}}=2121 \mathrm{~cm}^{-1}\right)$ in addition to the triplet multiplicity of the resonance for the terminal ruthenium hydride $\left(\delta_{\mathrm{H}}=-12.74, \mathrm{t},{ }^{2} J_{\mathrm{HP}}=23 \mathrm{~Hz}\right)$. The formulation was confirmed by a crystallographic study, the

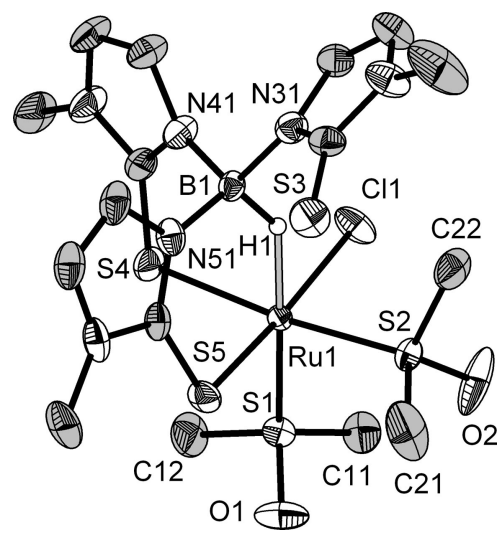

Figure 2. Molecular structure of $\left[\mathrm{RuCl}(\mathrm{dmso})_{2}\left\{\mathrm{HB}(\mathrm{mt})_{3}\right\}\right](3)$ in a crystal of $\mathbf{3} \cdot\left(\mathrm{CH}_{2} \mathrm{Cl}_{2}\right)_{0.5}$ (50\% displacement ellipsoids, carbonbound hydrogen atoms omitted, carbon atoms in gray). Selected distances ( $\AA$ ) and angles (deg): Ru1-Cl1 2.4431(14), Ru1-S1 2.2401(14), Ru1-S2 2.2798(14), Ru1-S4 2.4271(15), Ru1-S5 2.3467(14), Ru1-B1 2.817(6), Ru1-H1 1.84(6), B1-H1 1.14(6), Cl1-Ru1-S1 95.94(5), Cl1-Ru1-S2 87.91(5), S1-Ru1-S2 91.42(5), Cl1-Ru1-S487.08(6), S1-Ru1-S492.27(5), S1-Ru1-S5 88.41(5), S2-Ru1-S593.29(5), S4-Ru1-S591.46(6), Ru1-S4-C41 104.0(2), Ru1-S5-C51 103.82(19), Ru1-H1-B1 142(4). 


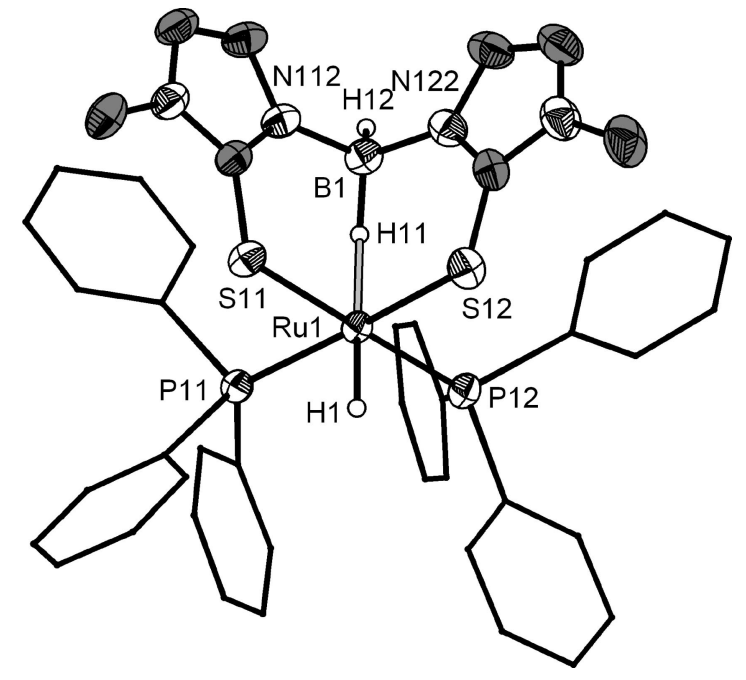

Figure 3. Molecular structure of $\left[\mathrm{RuH}\left(\mathrm{PPh}_{3}\right)_{2}\left\{\mathrm{H}_{2} \mathrm{~B}(\mathrm{mt})_{2}\right\}\right]$ (5) in a crystal of $\mathbf{5} \cdot\left(\mathrm{CH}_{2} \mathrm{Cl}_{2}\right)_{2}(50 \%$ displacement ellipsoids, carbon-bound hydrogen atoms omitted, carbon atoms in gray, phenyl groups simplified, one of two crystallographically independent molecules shown). Selected distances ( $₫$ ) and angles (deg): Ru1-S11 2.4374(7), Ru1-S12 2.4130(7), Ru1-P11 2.2871(7), Ru1-P12 2.2779(7), Ru1-B1 2.774(3), Ru1-H1 1.55(2), Ru1-H11 1.77(2), B1-H11 1.20(2), B1-H12 1.16(2), S11-Ru1-S12 87.64(3), S11-Ru1 P11 82.78(2), S12-Ru1-P12 89.68(3), P11-Ru1-P12 99.71(3),S11-Ru1-B179.79(7),S12-Ru1-B180.30(7),P11-Ru1-B1 104.81(7),P12-Ru1-B1 101.08(7),S11-Ru1-H190(1),S12-Ru1-H1 86(1), P11-Ru1-H1 87(1), P12-Ru1-H1 89(1), S11-Ru1-H11 91.3(8),S12-Ru1-H1193.0(8),P11-Ru1-H1194.3(8),P12-Ru1-H11 90.2(8),H1-Ru1-H11179(1),Ru1-S11-C111 103.4(1),Ru1-S12-C121 103.7(1), B1-H11-Ru1 138(2).

results of which are summarized in Figure 3, which depicts the approximate (though not crystallographically requisite) $C_{s}$ symmetry. This symmetry accounts for the chemical equivalence of the two phosphine ligands and the appearance of a single methimazolyl environment in the ${ }^{1} \mathrm{H}$ and ${ }^{13} \mathrm{C}\left\{{ }^{1} \mathrm{H}\right\}$ NMR spectra. The $\mathrm{Ru}-\mathrm{S}$ separations of $\mathrm{Ru} 1-\mathrm{S} 11$ 2.4374(7) and 2.4130(7) $\AA$ are somewhat disparate (35 esd), giving an indication that these are quite flexible in response to crystal packing effects and should therefore in general not be overinterpreted. The chelate bite angle $\left(87.64(3)^{\circ}\right)$ is somewhat smaller than that for $3\left(91.46(6)^{\circ}\right)$, presumably reflecting the increased steric congestion about ruthenium and reduced substitution at boron.

\section{Concluding Remarks}

The high-yielding product of the reaction of $\left[\mathrm{RuCl}_{2}(\mathrm{dmso})_{4}\right]$ with $\mathrm{Na}\left[\mathrm{HB}(\mathrm{mt})_{3}\right]$ has been shown to involve the less commonly encountered coordination of the $\mathrm{HB}(\mathrm{mt})_{3}$ ligand through one $\mathrm{B}-\mathrm{H}$ and two sulfur donors. A remarkable feature to emerge from the spectroscopic characterization of complex $\mathbf{3}$ is the unusually sharp and well-resolved multiplet ${ }^{1} \mathrm{H}$ resonance for the $\mathrm{B}-\mathrm{H}-\mathrm{Ru}$ group, for which at present we have no explanation. Although the synthesis of $\mathbf{3}$ was carried out in tetrahydrofuran, the workup and purification involved crystallization from dichloromethane over a time frame comparable to the originally reported synthesis of $\mathbf{2}$ executed in dichloromethane. We may therefore surmise that $\mathbf{3}$ is not an intermediate en route to $\mathbf{2}$ nor in solvent-dependent equilibrium with 2 .

(14) Dewhurst, R. D.; Hansen, A. R.; Hill, A. F.; Smith, M. K. Organometallics 2006, 25, 5843.

(15) Hallman, P. S.; Evans, D.; Osborn, J. A.; Wilkinson, G. Chem. Сотmun. 1967, 305.

\section{Experimental Section}

General Considerations. All manipulations were carried out under a dry and oxygen-free nitrogen atmosphere using standard Schlenk, vacuum line, and inert atmosphere drybox techniques, with dried and degassed solvents that were distilled from either calcium hydride $\left(\mathrm{CH}_{2} \mathrm{Cl}_{2}\right)$ or sodium-potassium alloy and benzophenone (ethers and paraffins). NMR spectra were obtained at $25^{\circ} \mathrm{C}$ on a Varian Gemini 300BB spectrometer $\left({ }^{1} \mathrm{H}, 299.945 \mathrm{MHz},{ }^{13} \mathrm{C}, 75.428\right.$ $\mathrm{MHz}$, referenced to residual protio-solvent peaks; ${ }^{31} \mathrm{P}, 121.420 \mathrm{MHz}$, ref external 85\% $\mathrm{H}_{3} \mathrm{PO}_{4} ;{ }^{11} \mathrm{~B}, 96.232 \mathrm{MHz}$, ref external $\left.\mathrm{BF}_{3} \cdot \mathrm{OEt}_{2}\right)$. Elemental microanalysis was performed by the microanalytical service of the Australian National University. Electrospray (ESI) and FAB mass spectrometry were performed by the Research School of Chemistry mass spectrometry service. Data for X-ray crystallography were collected with a Nonius Kappa CCD diffractometer. The compounds $\mathrm{Na}\left[\mathrm{HB}(\mathrm{mt})_{3}\right],{ }^{2 \mathrm{a}} \mathrm{Na}\left[\mathrm{H}_{2} \mathrm{~B}(\mathrm{mt})_{2}\right],{ }^{1 \mathrm{i}}[\mathrm{Ru}-$ $\left.\mathrm{Cl}_{2}(\mathrm{dmso})_{4}\right],{ }^{10}$ and $\left[\mathrm{RuHCl}\left(\mathrm{PPh}_{3}\right)_{3}\right] \cdot \mathrm{C}_{6} \mathrm{H}_{5} \mathrm{Me}^{15}$ were prepared according to the indicated published procedures. Other reagents were used as received from commercial suppliers.

Synthesis of [RuCl(dmso-S $\left.)_{2}\left\{\kappa^{3}-\mathbf{H}, \mathbf{S}, \mathrm{S}^{\prime}-\mathrm{HB}(\mathrm{mt})_{3}\right\}\right]$ (3). A mixture of $\left[\mathrm{RuCl}_{2}(\mathrm{dmso})_{4}\right]^{10}(0.20 \mathrm{~g}, 0.41 \mathrm{mmol})$ and $\mathrm{Na}\left[\mathrm{HB}(\mathrm{mt})_{3}\right]^{2 \mathrm{a}}$ $(0.16 \mathrm{~g}, 0.41 \mathrm{mmol})$ was stirred in THF $(30 \mathrm{~mL})$ at room temperature for 3 (or 24) h, after which time the reaction had changed from bright yellow to yellow-orange. The solvent was removed and the crude mixture was extracted with $\mathrm{CH}_{2} \mathrm{Cl}_{2}(2 \times$ $10 \mathrm{~mL})$ and filtered through diatomaceous earth. Ethanol $(10 \mathrm{~mL})$ was added to the filtrate and the solvent volume reduced (rotary evaporator) until a yellow-orange product precipitated. The product was filtered off, washed with ethanol $(10 \mathrm{~mL})$ and hexane $(10 \mathrm{~mL})$, and dried in vacuo for $3 \mathrm{~h}$. Yield $=0.16 \mathrm{~g}(60 \%$ based on dichloromethane hemisolvate). IR (Nujol): 2206w $v_{\mathrm{BHRu}}, 1648 \mathrm{wbr}$, $1565,1463 \mathrm{vs}, 1393 \mathrm{~s}, 1364 \mathrm{~m}, 1310,1266,1196 \mathrm{~s}, 1132,1095 \mathrm{vs} v_{\mathrm{SO}}$, $1016 \mathrm{~cm}^{-1}$. IR (THF): $2226 v_{\mathrm{BHRu}} \mathrm{cm}^{-1} .{ }^{1} \mathrm{H}$ NMR (298 K, $\left.\mathrm{CDCl}_{3}\right)$ : $\left.\delta-9.02\left(\mathrm{q}+\mathrm{h}, 1 \mathrm{H},{ }^{1} J\left({ }^{11} \mathrm{~B}^{1} \mathrm{H}\right)=71.6 \mathrm{~Hz},{ }^{1} \mathrm{~J}^{10}{ }^{10} \mathrm{~B}^{1} \mathrm{H}\right)=24.4 \mathrm{~Hz}\right)$, $3.15\left(\mathrm{NOE}\right.$ with $\left.\delta_{\mathrm{H}}-9.02\right), 3.37,3.38,3.44\left(\mathrm{~s} \times 4,3 \mathrm{H} \times 4, \mathrm{SCH}_{3}\right)$, $3.55,3.63,3.67\left(\mathrm{~s} \times 3,3 \mathrm{H} \times 3, \mathrm{NCH}_{3}\right), 6.74-6.77(\mathrm{~m}, 3 \mathrm{H}$, $\mathrm{NCHCH}), 6.91,6.99\left(\mathrm{NOE}\right.$ with $\left.\delta_{\mathrm{H}}=-9.02\right), 6.70(\mathrm{~s} \mathrm{br} \times 3,1 \mathrm{H}$ $\times 3, \mathrm{NCHCH}) \mathrm{ppm}$. The respective identities of $\mathrm{NCH}_{3}$ and $\mathrm{SCH}_{3}$ resonances were confirmed by HSQ correlations with resonances at $\delta_{\mathrm{C}} 33$ and $48 \mathrm{ppm}$, respectively. ${ }^{1} \mathrm{H}\left\{{ }^{11} \mathrm{~B}\right\} \mathrm{NMR}\left(298 \mathrm{~K}, \mathrm{CDCl}_{3}\right)$ : $\delta-9.07(\mathrm{~s}, 1 \mathrm{H}, \mathrm{B}-\mathrm{H}-\mathrm{Ru}), 3.09,3.31,3.32,3.38(\mathrm{~s} \times 4,3 \mathrm{H} \times 4$, $\left.\mathrm{SCH}_{3}\right), 3.49,3.56,3.60\left(\mathrm{~s} \times 3,3 \mathrm{H} \times 3, \mathrm{NCH}_{3}\right), 6.67-6.70(\mathrm{~m}$, $3 \mathrm{H}, \mathrm{NCHCH}), 6.94,6.97,6.98(\mathrm{~s}$ br $\times 3,1 \mathrm{H} \times 4 \mathrm{NCHCH}) \mathrm{ppm}$. ${ }^{11} \mathrm{~B}$ NMR $\left(298 \mathrm{~K}, d_{6}\right.$-dmso): $\delta 0.99\left(\mathrm{~d},{ }^{1} J_{\mathrm{BH}}=73.2 \mathrm{~Hz}\right) \mathrm{ppm}$. ${ }^{11} \mathrm{~B}\left\{{ }^{1} \mathrm{H}\right\}$ NMR $\left(278 \mathrm{~K}, d_{6}\right.$-dmso): $\delta 0.99 \mathrm{ppm} .{ }^{13} \mathrm{C}\left\{{ }^{1} \mathrm{H}\right\} \mathrm{NMR}(298$ $\left.\mathrm{K}, \mathrm{CDCl}_{3}\right): \delta$ 165.7(1CS), 163.8(2CS), 122.1(2C), 120.8, 120.2, $119.9,118.4(\mathrm{NCHCHN}), 47.51,47.13,46.67,46.14\left(\mathrm{SCH}_{3}\right)$, 36.16(1C), 35.01(2C, $\left.\mathrm{NCH}_{3}\right)$ ppm. FAB(+)-MS (nitrobenzyl alcohol): $m / z(\%) 545(10)[\mathrm{M}-\mathrm{H}]^{+}, 566(10)\left[\mathrm{HM}-\mathrm{dmso}^{+}, 530.2(10)\right.$ $\left[\mathrm{M}-\mathrm{HCl}-\mathrm{dmso}^{+}, 452.1(100)[\mathrm{M}-\mathrm{HCl}-2(\mathrm{dmso})]^{+}\right.$. ESI $(+)-\mathrm{MS}$ (MeCN): $m / z(\%) 644(2)[\mathrm{M}]^{+}, 589(3)\left[\mathrm{M}+\mathrm{Na}-\mathrm{dmso}^{+}, 567(28)\right.$ $[\mathrm{HM}-\mathrm{dmso}]^{+}, 470(100)\left[\mathrm{M}+\mathrm{H}_{2} \mathrm{O}-\mathrm{dmso}\right]^{+}, 453(92)[\mathrm{M}-\mathrm{dmso}]^{+}$. Anal. Found: C, 28.84; H, 4.33; N, 11.84. Calcd for $\mathrm{C}_{16} \mathrm{H}_{28^{-}}$ $\mathrm{BClN}_{6} \mathrm{O}_{2} \mathrm{~S}_{5} \mathrm{Ru} \cdot\left(\mathrm{CH}_{2} \mathrm{Cl}_{2}\right)_{0.5}$ : C, 28.87; H, 4.26; N, 12.24 (dichloromethane of solvation established crystallographically and by ${ }^{1} \mathrm{H}$ NMR integration). Crystals of a dichloromethane hemisolvate $\mathbf{3} \cdot\left(\mathrm{CH}_{2} \mathrm{Cl}_{2}\right)_{0.5}$ suitable for diffractometry were obtained by slow evaporation of a dichloromethane solution. Crystal data: $\mathrm{C}_{16} \mathrm{H}_{28^{-}}$ $\mathrm{BCIN}_{6} \mathrm{O}_{2} \mathrm{RuS}_{5} \cdot\left(\mathrm{CH}_{2} \mathrm{Cl}_{2}\right)_{0.5} ; M_{\mathrm{r}}=686.57$; triclinic; $P \overline{1}$ (No. 2); $a$ $=10.6309(2) \AA ; b=10.7378(4) \AA ; c=12.8683(4) \AA ; \alpha=$ 109.1434(13) ${ }^{\circ} ; \beta=93.297(2)^{\circ} ; \gamma=98.6958(18)^{\circ} ; V=1362.72(7)$ $\AA^{3} ; Z=2 ; D_{\mathrm{c}}=1.673 \mathrm{mg} \mathrm{m}^{-3} ; \mu(\mathrm{Mo} \mathrm{K} \alpha)=1.182 \mathrm{~mm}^{-1} ; T=$ $200(2) \mathrm{K}$, orange plate $0.04 \times 0.05 \times 0.20 \mathrm{~mm} ; 6226$ independent reflections, $F^{2}$ refinement, $R_{1}=0.0446, w R_{2}=0.1051$ for 30656 measured reflections; 4319 independent observed absorptioncorrected reflections $\left[I I \mid>2 \sigma(\mid I I), 2 \theta \leq 55^{\circ}\right], 316$ parameters, CCDC 693224. 
Synthesis of $\left[\mathbf{R u H}\left(\mathbf{P P h}_{3}\right)_{2}\left\{\boldsymbol{K}^{\mathbf{3}}-\mathbf{H}, \mathbf{S}, \mathbf{S}^{\prime}-\mathrm{H}_{2} \mathbf{B}(\mathbf{m t})_{2}\right\}\right](\mathbf{5})$. In a 100 $\mathrm{mL}$ Schlenk flask, $\left[\mathrm{RuHCl}\left(\mathrm{PPh}_{3}\right)_{3}\right] \cdot \mathrm{C}_{6} \mathrm{H}_{5} \mathrm{CH}_{3}{ }^{15}(0.25 \mathrm{~g}, 0.25 \mathrm{mmol})$ and $\mathrm{Na}\left[\mathrm{H}_{2} \mathrm{~B}(\mathrm{mt})_{2}\right]^{1 \mathrm{i}}(65 \mathrm{mg}, 0.25 \mathrm{mmol})$ were combined in dichloromethane $(20 \mathrm{~mL})$. The suspension was stirred at room temperature for $16 \mathrm{~h}$, during which time the reaction mixture changed from a dark purple suspension to a yellow solution with a white precipitate. The solution was filtered through diatomaceous earth and diluted with hexane, and the yellow product precipitated by reduction of the solvent volume by rotary evaporation. The yellow solid was collected on a glass sinter frit and recrystallized from a mixture of dichloromethane and hexane. Yield $=0.16 \mathrm{~g}$ (75\%). IR (Nujol): $2379 v_{\mathrm{BH}}, 2120 v_{\mathrm{BHRu}}, 1950 v_{\mathrm{RuH}} \mathrm{cm}^{-1}$. IR $\left(\mathrm{CH}_{2} \mathrm{Cl}_{2}\right): 2378 v_{\mathrm{BH}}, 2121 v_{\mathrm{BHRu}}, 1956 v_{\mathrm{RuH}} \mathrm{cm}^{-1}$. ${ }^{1} \mathrm{H}$ NMR $\left(\mathrm{C}_{6} \mathrm{D}_{6}\right.$, $298 \mathrm{~K}): \delta-12.74\left(\mathrm{t},{ }^{2} J_{\mathrm{HP}}=23 \mathrm{~Hz}, 1 \mathrm{H}, \mathrm{Ru} H\right),-5.7$ (s vbr, $1 \mathrm{H}$, $\mathrm{B}-\mathrm{H}-\mathrm{Ru}), 2.34\left(\mathrm{~s}, 6 \mathrm{H}, \mathrm{NCH}_{3}\right), 5.54,6.30(\mathrm{~s} \times 2,4 \mathrm{H}, \mathrm{NCH}=\mathrm{CH})$, 6.87-7.86 (m, 30H, $\left.\mathrm{C}_{6} \mathrm{H}_{5}\right)$ ppm. ${ }^{13} \mathrm{C}\left\{{ }^{1} \mathrm{H}\right\} \mathrm{NMR}\left(\mathrm{CD}_{2} \mathrm{Cl}_{2}, 298 \mathrm{~K}\right)$ : $\delta 167.4(\mathrm{CS}), 139.1\left[\mathrm{~d},{ }^{1} J_{\mathrm{CP}}=38 \mathrm{~Hz}, \mathrm{C}^{1}\left(\mathrm{C}_{6} \mathrm{H}_{5}\right)\right], 134.3\left[\mathrm{~d},{ }^{2} J_{\mathrm{CP}}=\right.$ $\left.5 \mathrm{~Hz}, \mathrm{C}^{2,6}\left(\mathrm{C}_{6} \mathrm{H}_{5}\right)\right], 127.7\left[\mathrm{C}^{4}\left(\mathrm{C}_{6} \mathrm{H}_{5}\right)\right], 126.5\left[\mathrm{~d},{ }^{3} J_{\mathrm{CP}}=5 \mathrm{~Hz}\right.$, $\left.\mathrm{C}^{3,5}\left(\mathrm{C}_{6} \mathrm{H}_{5}\right)\right], 120.7,120.3(\mathrm{~s} \times 2, \mathrm{NCH}=\mathrm{CH}), 34.01\left(\mathrm{NCH}_{3}\right) \mathrm{ppm}$. ${ }^{31} \mathrm{P}\left\{{ }^{1} \mathrm{H}\right\}$ NMR $\left(\mathrm{C}_{6} \mathrm{D}_{6}, 298 \mathrm{~K}\right): \delta 65.99 \mathrm{ppm}$. ESI(+)-MS: $\mathrm{m} / \mathrm{z}(\%)$ [assignment]: $865(30)[\mathrm{M}]^{+}, 603(100)\left[\mathrm{M}-\mathrm{PPh}_{3}\right]^{+}$. Anal. Found: C, 61.23; H, 5.34; N, 6.74. Calcd for $\mathrm{C}_{44} \mathrm{H}_{43} \mathrm{BN}_{4} \mathrm{P}_{2} \mathrm{RuS}_{2}$ : C, 61.04; $\mathrm{H}, 5.01 ; \mathrm{N}, 6.47$. Crystals of the bis(dichloromethane) solvate suitable for diffractometry were grown by slow diffusion of hexane into a concentrated dichloromethane solution of the complex at -18 ${ }^{\circ} \mathrm{C}$. Crystal data: $\mathrm{C}_{44} \mathrm{H}_{43} \mathrm{BN}_{4} \mathrm{P}_{2} \mathrm{RuS}_{2} \cdot\left(\mathrm{CH}_{2} \mathrm{Cl}_{2}\right)_{2} ; M_{\mathrm{r}}=1035.67$; triclinic; $P \overline{1}$ (No. 2); $a=13.6077(1) \AA ; b=19.4945(2) \AA ; c=$ 20.7775(2) $\AA$; $\alpha=105.8160(6)^{\circ} ; \beta=100.3594(6)^{\circ} ; \gamma=$
Scheme 2

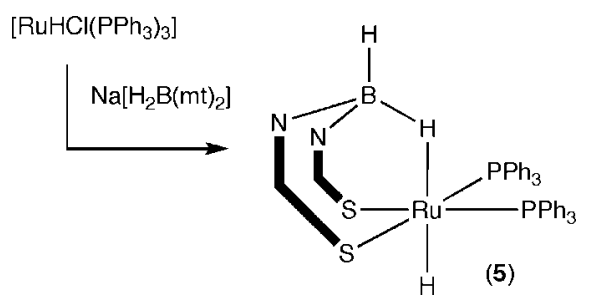

109.6253(5) ${ }^{\circ} ; V=4765.85(8) \AA^{3} ; Z=4 ; D_{x}=1.443 \mathrm{mg} \mathrm{m}^{-3}$; $\mu(\mathrm{Mo} \mathrm{K} \alpha)=0.74 \mathrm{~mm}^{-1} ; T=200(2) \mathrm{K}$, yellow plate $0.08 \times 0.26$ $\times 0.30 \mathrm{~mm} ; 104738$ measured reflections, 21781 independent reflections, $F$ refinement, $R_{1}=0.0424, w R_{2}=0.0509$ for 15857 independent absorption-corrected reflections [ $[I \mid>3 \sigma(|I|), 2 \theta<55]$, 1135 parameters (CCDC 693223).

Acknowledgment. We thank the Australian Research Council (ARC) for financial support (Grant Nos. DP0771497, DP0881692) and the University of Botswana for a studentship (to N.T.).

Supporting Information Available: Full details of the crystal structure determinations of $\mathbf{3} \cdot\left(\mathrm{CH}_{2} \mathrm{Cl}_{2}\right)_{0.5}(\mathrm{CCDC}$ 693224) and 5. $\left(\mathrm{CH}_{2} \mathrm{Cl}_{2}\right)_{2}(\mathrm{CCDC} 693223)$ in CIF format; in situ ${ }^{1} \mathrm{H}$ NMR spectra of crude reaction mixtures. This material is available free of charge via the Internet at http://pubs.acs.org. 